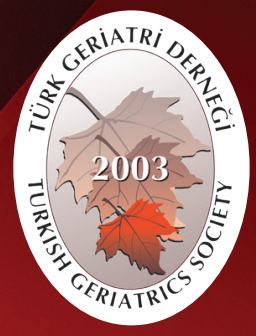

Turkish Journal of Geriatrics

DOI: $10.31086 /$ tigeri.2018240416

2018:21 (2):157-165

- Berna ŞENEL ERASLAN

- Ibrahim ERAY ÇAKI ${ }^{1}$

- Beytullah KARADAYI ${ }^{1}$

- Abdi ÖZASLAN

\title{
A STUDY ON PHYSICIANS' PERSPECTIVES ON ELDER ABUSE AND NEGLECT
}

\section{Abstract}

Introduction: Rapid developments in science and technology, increased quality of life, and developments in in methods for diagnosing and treating diseases have led to an increased geriatric population worldwide. This is associated with an increased risk of elder abuse and neglect. In the present study, we aimed to evaluate physicians' perspectives on elder abuse and neglect, to understand their knowledge and approaches, to raise awareness on the subject, and to identify the abuse and offer suggestions to resolve it.

Materials and Method: This study was conducted on 524 volunteer physicians working at public institutions and hospitals or private hospitals and private clinics. They completed a questionnaire including questions evaluating physicians' demographic characteristics, education regarding elder abuse and neglect, diagnostic approaches, and knowledge about the approach to elder abuse and neglect. Data were analyzed using descriptive statistics and graphical analysis using SPSS 21.0 software.

Findings: Forty five percent of the physicians indicated that they encountered elder abuse and neglect. Neglect was most common, with $37.4 \%$ of physicians reporting this. Only $24.3 \%$ of the physicians who encountered elder abuse and neglect stated that they had notified the authorities of the same. When the physicians were asked for their reasons for not reporting elder abuse and neglect cases, the most common response (62.3\%) was concern that the older person could be harmed further.

Conclusion: Based on our findings, necessary legal arrangements should be made to provide home care for the older persons, families should be financially supported, research into this topic should be conducted, and propose solutions should be developed.

Keywords: Elder Abuse; Physician; Jurisprudence

\section{ARAŞTIRMA}

CORRESPONDANCE

Berna ŞENEL ERASLAN

Istanbul University, Cerrahpaşa Medical

Faculty, Department of Forensic Medicine, istanbul, Turkey

Phone: 2124143029

Fax: 2124143028

e-mail: drbsenel@gmail.com

Received: $01 / 02 / 2018$

Accepted: $27 / 04 / 2018$

İstanbul University, Cerrahpaşa Medical Faculty, Department of Forensic

Medicine, İstanbul, Turkey

\section{HEKIMLERIN YAŞLI ISTISMARINA VE IHMALINE BAKIŞ AÇISINI DEĞERLENDIREN BíR ÇALIŞMA}

\section{$\ddot{O}_{z}$}

Giriş: Bilim ve teknolojideki hızlı ilerleyiş, yaşam kalitesindeki artış, hastalıkların tanı ve tedavi yöntemlerinin gelişmesi dünyadaki yaşlı nüfusun artmasına yol açmıştır. Bu durum yaşlının istismar ve ihmal edilme riskini artırmaktadır. Bu çalışmada; hekimlerin yaşlı istismar ve ihmaline bakış açılarını değerlendirmek, bilgi ve yaklaşımlarını öğrenmek, konuya farkındalık kazandırmak, istismarın tespit edilmesi ile çözümüne yönelik öneriler sunulması hedeflendi.

Gereç ve Yöntem: Araştırma, Türkiye'de kamu kuruluşu hastanelerinde ya da özel hastane ve muayenehanelerde görev yapan 524 gönüllü doktor üzerinde gerçekleştirildi. Ankette; hekimlere ait demografik özellikler, yaşıı istismarı ve ihmali konusunda aldıkları eğitimler, ihmal deneyimleri, tanıda izledikleri yollar, olguya yaklaşım ve inmal konusundaki bilgi düzeylerini ölçen soruları içermektedir. Elde edilen veriler SPSS 21.0 istatistik programı kullanılarak tanımlayıcı istatistik ve grafik analizi ile değerlendirildi.

Bulgular: Mesleki uygulamaları sırasında hekimlerin \%45.0'ı yaşı istismarı ve ihmali ile karşılaştığını belirtti. En sık karşılaşılan tür \%37.4 sıklık ile ihmal olarak tespit edildi. Yaşı istismarı ve ihmali ile karşılaştığını belirtenlerin sadece \%24.3'ü bu konuda resmi makamlara bildirimde bulunduğunu belirtti. Hekimlere adli olgu bildiriminde bulunmama nedenleri sorgulandığında ise en fazla işaretlenen seçeneğin \%62.3 ile yaşlının zarar görebileceği endişesi olduğu görüldü.

Sonuç: Yaşlılara evde bakımın temin edilebilmesi için gerekli yasal düzenlemeler yapılmalı, bu konuda aileler ekonomik açıdan desteklenmeli, konuya yönelik araştırmalar yapılmalı ve bu verilere dayalı olarak çözüm önerileri geliştirilmelidir.

Anahtar sözcükler: Yaşlı İstismarı; Hekim; Yasal yükümlülük 


\section{INTRODUCTION}

Rapid developments in science and technology, increased quality of life, and developments in the methods of diagnosis and the treatments of diseases have resulted in an increased mean human lifespan. As a result, the geriatric population increases every year (1). While the size of the population was 542 million in 1995, it has been estimated to rise to approximately 1.2 billion by 2025 (2). This situation is similar in Turkey. Data from the Turkish Statistical Institute for 2016 revealed that while the size of the geriatric population was $5,682,003$ in 2012 , it increased by $17.1 \%$ in the last five years and was reported to be 6,651,503 in 2016 (3).

Aging is associated with various problems including decline in physical and cognitive functions, financial difficulties, health issues and decreased social support. With modernization of traditional society of Turkey, younger generations are paying lesser attention to the care of older relatives (4). Consequently, difficulties experienced during the care of an older person individually at home or in an institution increases the risk of abuse and neglect.

According to the Toronto Declaration by the World Health Organization (WHO), elder abuse is defined as "single or recurrent inappropriate behavior that harms or distresses to an older people in a relationship based on trust expectation" (5). This definition includes physical, emotional, sexual, and economical abuse and neglect.

Physicians also witness elder abuse and neglect while making diagnoses and during treatment. Physicians have an important role in determining the findings of abuse and neglect, reporting suspected cases and discovering barriers and supports in the detection and management of elder abuse cases $(6,7,8)$.

The present study aimed to evaluate the perspective of physicians on elder abuse and neglect, to understand their knowledge and approaches, to raise awareness on the subject, and to offer possible solutions.

\section{MATERIALS AND METHOD}

\section{Study design and participants}

A total of 524 physicians including practitioners, specialists, and academics with medical background from public hospitals or private hospitals and private clinics in Turkey participated in this descriptive study. In this study, convenience sampling method was used to generate the sample. Questionnaire forms prepared for this study were administered via an online platform exclusively for physicians where around 15000 physicians all across Turkey were members of or as printed materials to voluntary participants. The sample size was calculated as 375 with $95 \%$ confidence interval level, 50\% frequency and 10\% sampling error. Incorrect filling of questionnaire and ratio of replies being under $80 \%$ are accepted as exclusion criteria, 450 people were targeted to minimize the sampling error. The number of participants in this study corresponds the minimal sampling size. The participants were informed about the topic and purpose of the study and were assured that the information they provided was only going to be used for the study and was strictly confidential. Physicians were asked to answer questions in relation to their thoughts and knowledge. The questionnaire included 24 questions, of which the first six were prepared as a data collection tool to determine the sociodemographic characteristics (such as age, gender, marital status, specialty, professional experience) of physicians. The latter questions to evaluate physicians' perspectives on elder abuse and neglect, education, types of elder abuse encountered, diagnosis criteria, and approach to cases and were presented as multiplechoice questions.

\section{Statistical analysis}

The data obtained from the researchers were transferred to the computer. Data were analyzed with descriptive statistics and graphical analyses using SPSS 21.0 statistical analysis software (SPSS Inc. Chicago, IL, USA). The chi-square test was used 
to compare the groups. $p<0.05$ was considered to be statistically significant. While evaluating the questionnaires, it was noticed that physicians did not answer some questions; therefore, statistical analyses were conducted using appropriate valid data.

\section{Ethical considerations}

The study was approved by the Ethical Board at the Faculty of Medicine at Istanbul University on 03.16.2017 (Number: 53239941-604.01.02-104683).

\section{RESULTS}

Of the 524 physicians who agreed to participate, $68.7 \%$ were female, $31.3 \%$ were male, $74.7 \%$ were married, $25.3 \%$ were single, $79.3 \%$ worked in public institutions, and $20.7 \%$ worked in the private sector. Furthermore, $42.1 \%$ of the participants were practitioners, while $51.1 \%$ and $6.7 \%$ were specialists and academics with a medical background, respectively. The mean age was $36.2 \pm 8.3$ years, and the mean duration of professional experience was $12.2 \pm 8.5$ years.

Sixty percent of the physicians stated that care support was given to the older persons in their homes (mostly grandparents) and that the average care period was 4.4 years.

Totally, $56.9 \%$ of the physicians considered patients older than 65 years to be older persons.

A total of $90.6 \%$ of the physicians stated that they were obliged to report elder abuse to the authorities.

Almost half (45.0\%) of the physicians stated that they encountered elder abuse and neglect during their practice. The types of abuse they encountered were neglect (37.4\%), emotional abuse (25.1\%), economic abuse (22.2\%), physical abuse (15.7\%), and sexual abuse (1.1\%). Only $24.3 \%$ of the physicians who encountered abuse and neglect reported it to the authorities. When the physicians were asked about their reasons for not reporting abuse to the authorities, the main reason (62.3\%) was concern that the older person would suffer (Figure 1).

When the physicians were asked about under which circumstances they suspect about the abuse of older people; the most frequent response was "the presence of numerous physical trauma traces on the body that are in different healing stages". When the same question was repeated for elder neglect, the most common answer was "insufficient hygiene and care of nails, hair, beard, mouth, body, and clothes" (Table 1).

When asked about the physicians' approach in cases that were determined to be elder abuse, $55.1 \%$ of the physicians stated that they reported such cases to the police without informing the family. When the same question was repeated for elder neglect, $24.8 \%$ of the physicians stated that they reported such cases to social services and $21.3 \%$ of them informed law enforcement agencies (Table 2).

Physicians' obligations to report elder abuse and neglect were compared according to whether they had received education. The reporting rate of the educated group to the authorities was higher than that in the group without education, and this difference was statistically significant $(p<0.001)$. Similarly, the educated group reported a higher rate of encountering elder abuse $(p=0.04)$ and suggested that "they feel sufficient about elder abuse," "previous notifications were not useful," and "governments did not provide older victims enough support" at a higher rate than the other group ( $p=0.01, p=0.04$, and $p=0.006$, respectively; Table 3). The educated group defined "older person" as an "individual older than 65 years" at a higher rate than the group without education on the subject $(p=0.026)$. Similarly, the educated group defined the period of old age as a "period of resting/peaceful life" at a higher rate $(p=0.02)$ than the group without education on the subject but defined it as a "period of dependence/neediness 
from others" at a lower rate $(p=0.02)$ than the group without education on the subject.

When the answers of the physicians were compared taking gender into account, it was observed that female physicians encountered elder abuse and neglect at a higher rate than their male counterparts $(p=0.006)$, while there was no difference between the two genders for reporting cases $(p=0.35)$ (Table 3 ).

When the physicians were compared according to the sectors they worked in, those in the public sector had higher education about the subject $(p=0.004)$ and higher rates of reporting $(p=0.005)$ than those in the private sector (Table 3 ).

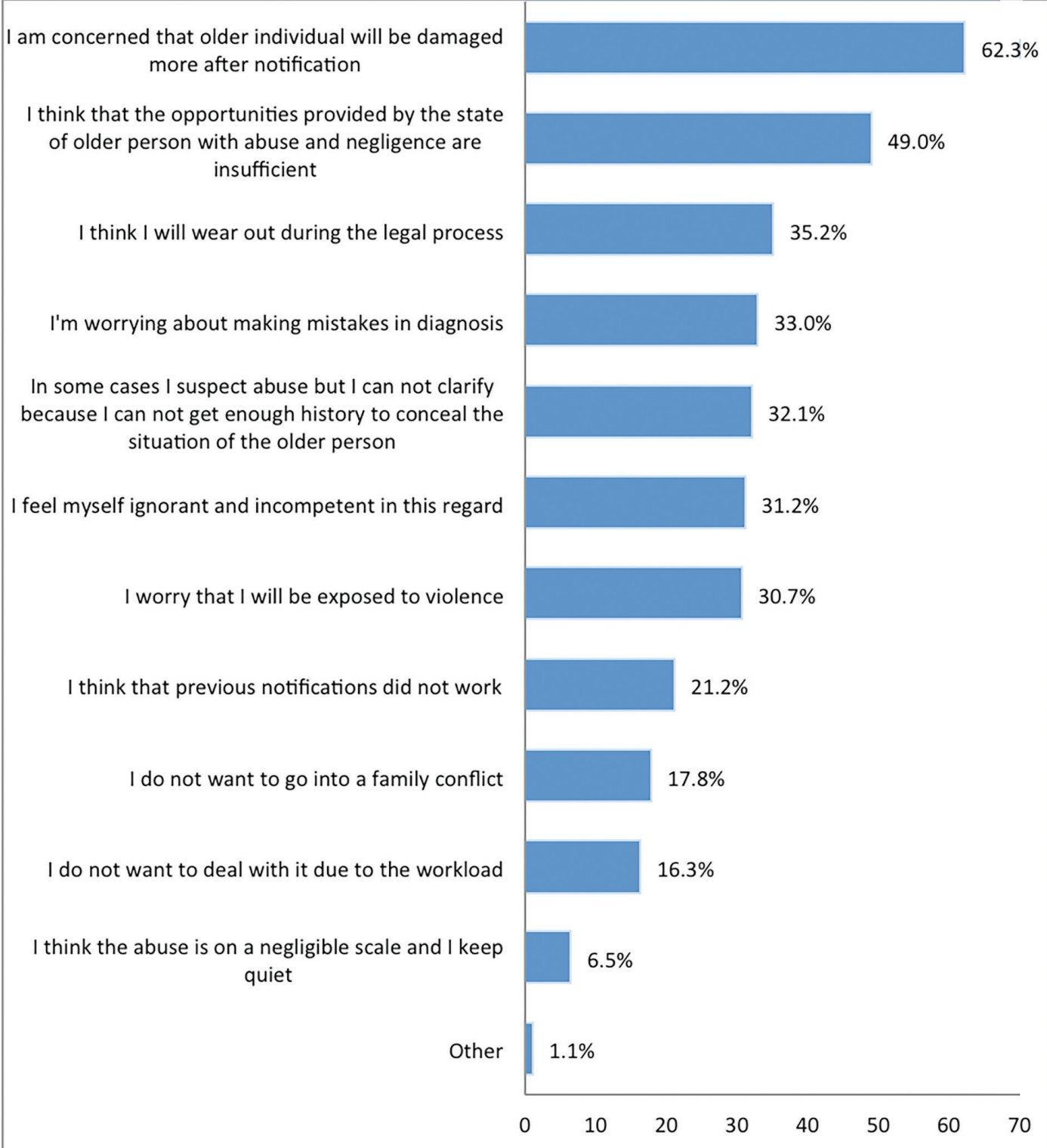

Figure 1. Reasons for physicians not reporting elder abuse. 
Table 1. Situations raising doubt of elder abuse and neglect.

n

\section{Situations raising suspicion of abuse*}

Presence of numerous physical trauma traces on the body that are in different healing stages

Although the older person has economic power, the basic needs of the older person have not been met and their financial resources have been used by relatives

Older person in a cowardly, timid manner while in a relationship with family members

Presence of suspicious genital or anal wound(s)

Presence of delayed or untreated disease(s) in the older person

\section{Situations raising suspicion of neglect*}

Inadequate nail, hair, beard, and mouth care; body hygiene; and laundry cleaning

Failing to meet the basic needs of the older person while having enough financial power

Presence of delayed or untreated disease(s) in the older person

Inadequate nutrition of the older person despite adequate financial power in the family

The care of the family (according to economic power) can not meet the social needs of the older person

No communication between family members and the older person other than to meet basic care needs

* For both of the questions, the participants were allowed to choose more than one choice.

Table 2. Approach to cases in which physicians are convinced that elder abuse and neglect.

\begin{tabular}{lr}
\hline & $\mathbf{n}$ \\
\hline Approach to cases determined to be abuse* & \% \\
Make a direct police statement without informing the family & 284 \\
I definitely take the advice of the older person about reporting and act in accordance with & 55.1 \\
his/her requirements & 119 \\
I inform the family and tell them that if it is repeated, I will inform the police & 90 \\
I remain silent & 1 \\
Others & 23.1 \\
Approach to cases determined to be neglect* & 0.2 \\
I notify the social services & 4.1 \\
I report it to the hospital police/law enforcement & 127 \\
I apply a multidisciplinary approach (consultation) & 109 \\
I inform family members & 100 \\
I take the advice of the older person about reporting and act in accordance with & 21.3 \\
his/her requirements & 19.5 \\
I ask for support from the forensics department & 15.4 \\
I remain silent & 14.1 \\
Others & 21 \\
\hline
\end{tabular}

\footnotetext{
* Some of the participants did not answer these questions.
} 
Table 3. Comparison of physicians' education status in elder abuse and neglect.

\begin{tabular}{|c|c|c|c|c|c|c|c|c|c|c|c|c|c|c|}
\hline \multirow{4}{*}{\multicolumn{2}{|c|}{$\begin{array}{l}\text { Do you think that the physician has an obliga- } \\
\text { tion to officially report cases of elder abuse and } \\
\text { neglect? }\end{array}$}} & & \multicolumn{4}{|c|}{$\begin{array}{l}\text { Did you receive education on elder } \\
\text { abuse and neglect? }\end{array}$} & \multicolumn{4}{|c|}{ Gender } & \multicolumn{4}{|c|}{ Sector } \\
\hline & & & \multirow{2}{*}{\begin{tabular}{l|} 
Yes \\
$94.9 \%$
\end{tabular}} & \multirow{2}{*}{\begin{tabular}{|c|} 
No \\
$89.9 \%$ \\
\end{tabular}} & \multirow{2}{*}{\begin{tabular}{r|} 
Value \\
1.955
\end{tabular}} & \multirow{2}{*}{$\frac{p}{p}$} & \multirow{2}{*}{\begin{tabular}{|r|} 
Female \\
$91.6 \%$ \\
\end{tabular}} & \multirow{2}{*}{\begin{tabular}{|c|} 
Male \\
$88.4 \%$ \\
\end{tabular}} & \multirow{2}{*}{\begin{tabular}{|c|} 
Value \\
1.359 \\
\end{tabular}} & \multirow{2}{*}{$\frac{p}{0.24}$} & \multirow{2}{*}{$\begin{array}{r}\text { Public } \\
91,7 \%\end{array}$} & \multirow{2}{*}{\begin{tabular}{|l|} 
Private \\
$86,9 \%$ \\
\end{tabular}} & \multirow{2}{*}{\begin{tabular}{|r|} 
Value \\
2,264
\end{tabular}} & \multirow{2}{*}{$\frac{p}{0,132}$} \\
\hline & & Yes & & & & & & & & & & & & \\
\hline & & No & $5.1 \%$ & $10.1 \%$ & & & $8.4 \%$ & $11.6 \%$ & & & $8,3 \%$ & $13,1 \%$ & & \\
\hline \multirow{2}{*}{\multicolumn{2}{|c|}{$\begin{array}{l}\text { Have you ever encountered elder abuse and ne- } \\
\text { glect during your professional practice? }\end{array}$}} & Yes & $55.8 \%$ & $43.1 \%$ & 4.276 & 0.04 & $49.0 \%$ & $36.2 \%$ & 7.454 & 0.006 & $46,7 \%$ & $38,7 \%$ & 2,187 & 0,139 \\
\hline & & No & $44.2 \%$ & $56.9 \%$ & & & $51.0 \%$ & $63.8 \%$ & & & $53,3 \%$ & $61,3 \%$ & & \\
\hline \multirow{2}{*}{\multicolumn{2}{|c|}{$\begin{array}{l}\text { Did you officially report it when you encountered } \\
\text { elder abuse cases? }\end{array}$}} & Yes & $41.7 \%$ & $14.9 \%$ & 18.647 & $<0.001$ & $17.8 \%$ & $22.5 \%$ & 0.882 & 0.35 & $21,7 \%$ & $10,3 \%$ & 3,829 & 0,050 \\
\hline & & No & $58.3 \%$ & $85.1 \%$ & & & $82.2 \%$ & $77.5 \%$ & & & $78,3 \%$ & $89,7 \%$ & & \\
\hline \multirow{22}{*}{$\begin{array}{l}\text { What are the reason(s) for } \\
\text { not informing officials in } \\
\text { case of encountering elder } \\
\text { abuse and neglect }\end{array}$} & \multirow{2}{*}{$\begin{array}{l}\text { A. I think the abuse } \\
\text { is insignificant, and I } \\
\text { remain silent }\end{array}$} & Yes & $9.2 \%$ & $6.1 \%$ & 0.909 & 0.34 & $6.2 \%$ & $7.3 \%$ & 0.191 & 0.66 & $6,9 \%$ & $5,6 \%$ & 0,182 & 0,670 \\
\hline & & No & $90.8 \%$ & $93.9 \%$ & & & $93.8 \%$ & $92.7 \%$ & & & $93,1 \%$ & $94,4 \%$ & & \\
\hline & \multirow{2}{*}{$\begin{array}{l}\text { B. I do not want to } \\
\text { get into a family con- } \\
\text { flict }\end{array}$} & Yes & $18.5 \%$ & $17.7 \%$ & 0.023 & 0.88 & $16.3 \%$ & $21.2 \%$ & 1.543 & 0.21 & $18,6 \%$ & $14,6 \%$ & 0,782 & 0,376 \\
\hline & & No & $81.5 \%$ & $82.3 \%$ & & & $83.7 \%$ & $78.8 \%$ & & & $81,4 \%$ & $85,4 \%$ & & \\
\hline & \multirow{2}{*}{$\begin{array}{l}\text { C. I feel ignorant and } \\
\text { incompetent in this } \\
\text { regard }\end{array}$} & Yes & $13.8 \%$ & $34.3 \%$ & 10.559 & 0.001 & $32.6 \%$ & $27.7 \%$ & 1.034 & 0.31 & $31,2 \%$ & $29,2 \%$ & 0,136 & 0,713 \\
\hline & & No & $86.2 \%$ & $66.0 \%$ & & & $67.4 \%$ & $72.3 \%$ & & & $68,8 \%$ & $70,8 \%$ & & \\
\hline & \multirow{2}{*}{$\begin{array}{l}\text { D. I do not want to } \\
\text { deal with it due to } \\
\text { workload }\end{array}$} & Yes & $13.8 \%$ & $16.6 \%$ & 0.315 & 0.58 & $15.6 \%$ & $17.5 \%$ & 0.247 & 0.62 & $18,6 \%$ & $6,7 \%$ & 7,373 & 0,007 \\
\hline & & No & $86.2 \%$ & $83.4 \%$ & & & $84.4 \%$ & $82.5 \%$ & & & $81,4 \%$ & $93,3 \%$ & & \\
\hline & \multirow{2}{*}{$\begin{array}{l}\text { E. I worry that I will be } \\
\text { exposed to violence }\end{array}$} & Yes & $32.3 \%$ & $30.3 \%$ & 0.101 & 0.75 & $27.7 \%$ & $37.2 \%$ & 4.057 & 0.04 & $31,5 \%$ & $27,0 \%$ & 0,692 & 0,405 \\
\hline & & No & $67.7 \%$ & $69.7 \%$ & & & $72.3 \%$ & $62.8 \%$ & & & $68,5 \%$ & $73,0 \%$ & & \\
\hline & \multirow{2}{*}{$\begin{array}{l}\text { F. I think that I will be } \\
\text { worn out during the } \\
\text { legal process }\end{array}$} & Yes & $36.9 \%$ & $34.8 \%$ & 0.107 & 0.744 & $30.9 \%$ & $44.5 \%$ & 7.666 & 0.006 & $34,4 \%$ & $37,1 \%$ & 0,227 & 0,634 \\
\hline & & No & $63.1 \%$ & $65.2 \%$ & & & $69.1 \%$ & $55.5 \%$ & & & $65,6 \%$ & $62,9 \%$ & & \\
\hline & \multirow{2}{*}{$\begin{array}{l}\text { G. I am worried about } \\
\text { making mistakes in } \\
\text { the diagnosis }\end{array}$} & Yes & $23.1 \%$ & $34.6 \%$ & 3.318 & 0.07 & $34.5 \%$ & $29.2 \%$ & 1.220 & 0.27 & $33,5 \%$ & $30,3 \%$ & 0,326 & 0,568 \\
\hline & & No & $76.9 \%$ & $65.4 \%$ & & & $65.5 \%$ & $70.8 \%$ & & & $66,5 \%$ & $69,7 \%$ & & \\
\hline & \multirow{2}{*}{$\begin{array}{l}\text { H. I think that previ- } \\
\text { ous notifications did } \\
\text { not work }\end{array}$} & Yes & $30.8 \%$ & $19.5 \%$ & 4.203 & 0.04 & $20.2 \%$ & $23.4 \%$ & 0.568 & 0.45 & $21,5 \%$ & $21,3 \%$ & 0,001 & 0,977 \\
\hline & & No & $69.2 \%$ & $80.5 \%$ & & & $79.8 \%$ & $76.6 \%$ & & & $78,5 \%$ & $78,7 \%$ & & \\
\hline & $\begin{array}{l}\text { 1. I am concerned that } \\
\text { the older person will }\end{array}$ & Yes & $55.4 \%$ & $63.3 \%$ & 1.487 & 0.22 & $62.2 \%$ & $62.0 \%$ & 0.001 & 0.97 & $61,0 \%$ & $67,4 \%$ & 1,231 & 0,267 \\
\hline & $\begin{array}{l}\text { be harmed further } \\
\text { after the notification }\end{array}$ & No & $44.6 \%$ & $36.7 \%$ & & & $37.8 \%$ & $38.0 \%$ & & & $39,0 \%$ & $32,6 \%$ & & \\
\hline & J. In some cases, I & Yes & $29.2 \%$ & $32.5 \%$ & 0.265 & 0.60 & $34.5 \%$ & $26.3 \%$ & 2.964 & 0.09 & $33,0 \%$ & $30,3 \%$ & 0,221 & 0,638 \\
\hline & $\begin{array}{l}\text { cannot clarify it be- } \\
\text { cause I cannot obtain } \\
\text { enough history to } \\
\text { disclose the situation } \\
\text { of the older person }\end{array}$ & No & $70.8 \%$ & $67.5 \%$ & & & $65.5 \%$ & $73.7 \%$ & & & $67,0 \%$ & $69,7 \%$ & & \\
\hline & K. I think that the pro- & Yes & $64.6 \%$ & $46.2 \%$ & 7.551 & 0.006 & $50.2 \%$ & $46.0 \%$ & 0.662 & 0.42 & $47,3 \%$ & $53,9 \%$ & 1,257 & 0,262 \\
\hline & $\begin{array}{l}\text { for abused and ne- } \\
\text { glected older people } \\
\text { are insufficient }\end{array}$ & No & $35.4 \%$ & $53.8 \%$ & & & $49.8 \%$ & $32.6 \%$ & & & $52,7 \%$ & $46,1 \%$ & & \\
\hline
\end{tabular}




\section{DISCUSSION}

The WHO defines individuals older than 65 years as older person. A study that evaluated the perspectives of university students on older individuals showed that $57.8 \%$ of the participants considered individuals who were 60-65 years old as older person, while $27.8 \%$ considered individuals aged between 68 and 80 years to be older person (9). In the present study, $56.9 \%$ of the physicians considered individuals older than 65 years to be older person, as defined by the $\mathrm{WHO}$, while $21.0 \%$ considered individuals older than 70 years to be older person. The reason for this might be an increased mean lifespan in conjunction with developments in medicine during the last years.

While $45.0 \%$ of the physicians encountered elder abuse and neglect during their professional practice, they most frequently encountered neglect (37.4\%), emotional abuse (25.1\%), economic abuse (22.2\%), physical abuse (15.7\%), and sexual abuse (1.1\%). This study, neglect had the highest rate, similar to studies conducted in the Japan (10). Physical abuse was the primary type of abuse demonstrated in studies conducted in the South Korea (11). Sexual abuse was the least common type, similar to studies conducted in Ireland (8). The potential reason for these differences is different cultures and lifestyle in the countries.

Article 280 of the Turkish Penal Code No. 5237 (TCK) states that if a physician identifies a symptom of a crime being committed while performing his/her duties, if he/he does not report it to the authorities or is late in reporting, he/she can be punished with imprisonment for a period of up to one year (12). In the present study, there was a clear consensus (90.6\%) among the physicians that elder abuse and neglect is a crime that must be reported to the authorities.
Healthcare staff must consider legal notifications as an exception to patient confidentiality. A physician's obligation to report such cases arises from the need to take precautions in matters involving following up crimes, arresting offenders, and maintaining public health. While this rationale is related to "public interest," it should not be implemented in such a manner as to ignore basic patient rights. If a person requiring treatment is involved in any crime or is victim to any criminal offense committed, it is the obligation of the healthcare professional who has discovered this during their professional practice to notify the appropriate authorities and not keep any information confidential. The present study revealed that $45.0 \%$ of the physicians indicated that they encountered elder abuse and neglect but that only $24.3 \%$ of them notified the authorities. An investigation into the reasons why physicians did not notify the authorities revealed that their greatest concern was that the older individual would be harmed further after notification (62.3\%), followed by the belief that state provisions for abused and neglected older people were insufficient (49.0\%; Fig. 1). Same concern about the future life quality of older person was also mentioned in a study conducted in USA (13). Accordingly, there is an apparent clash in legal and ethical responsibilities. On the other hand, it is clear that physicians make their evaluations considering their ethical responsibilities and have an ethical approach to the subject.

From previous studies, it can be seen that within the scope of providing health services, females are more at risk of being verbally violated, while males are more at risk of being physically violated (14). In the present study, it was observed that male physicians were more concerned about "being physically violated" and "being worn out during the legal process" after notifying the authorities than female physicians. 
The evaluation of whether the physicians had received any education on elder abuse and neglect showed that only $14.9 \%$ of the physicians had received such an education. A statistical comparison of the group that was educated on elder abuse and neglect and the group that had not been educated on elder abuse and neglect, the obligation of notification to the authorities revealed that the group that was educated had higher rates of identifying abuse and neglect as well as notifying the authorities. This is because of the natural awareness of the physicians who had been educated and their increased sensitivity to the subject. It was determined that most physicians do not question geriatric patients about abuse because of inadequate knowledge on detection, management, the protocol surrounding the subject, legislations, and referral to appropriate institutions. Kennedy, Taylor and Schmeidel emphasize similar reasons (15-17). In a study conducted by Polat et al., it was suggested that health professionals have insufficient knowledge, skills, and attitudes about issues such as physical, sexual, emotional, and economic abuse and evaluation, monitoring, reporting, and legal initiatives (18). The group that was educated about elder abuse stated that "they feel sufficient about elder abuse" more than the group that had not received education on the subject. Previous studies have shown that educational intervention has an important influence on gaining experience, awareness, and knowledge (19-21). In the present study, it was determined that the group that was educated about the subject stated that "previous notifications to the authorities were not useful" and "governments did not provide older victims with enough support" at a higher rate than the group that was not educated on the subject. These data are valuable because together with increased knowledge, physicians start the legal process; however, at the end of the process, the result did not meet their expectations.
When the physicians were asked what situations triggered suspicion of elder neglect, $91.4 \%$ responded "Inadequate nail, hair, beard, and mouth care; body hygiene; and laundry cleaning." "No communication between family members and the older person other than to meet basic care needs" was the least common response (56.8\%). The reason for this situation was thought to be due to a false social perception that only physical needs are met so that the older individual can survive and that the social and emotional needs of the older person can be ignored. Moreover, this false perception was interiorized among physicians in daily life as Sorenson mentioned (22). Due to this fact, during examination of older patient physicians are trying to limit their communication to shorten the duration of visit.

In conclusion, it is very difficult to uncover and identify elder abuse and neglect. This is because of reasons such as concerns of repeated exposure to violence and breaking ties with family members as well as the inability to deal with feelings of guilt due to the complainant.

When a physician finds any evidence of abuse during his/her intervention, it is his/her obligation to notify the appropriate authorities, even if the abuser is a close relative of the victim.

In-house education programs should be organized for physicians to prevent violence and abuse towards the older persons.

Concerns of physicians regarding their legal obligation to notify the authorities and the potential risks associated should be addressed.

Necessary legal arrangements should be made for care of the older person at home, and families providing care for the older person should be financially supported.

The number of organizations, such as shelters and care homes for older people, should be increased where victims can report abuse and violence and receive help. 


\section{REFERENCES}

1. Yunus RM, Hairi NN, Choo WY. Consequences of elder abuse and neglect: a systematic review of observational studies. Trauma, Violence, \& Abuse 2017 February 22;(1):1-17. (PMID:29333999).

2. Krug EG, Dahlberg LL, Mercy JA, et al. World report on violence and health, World Health Organization, Geneva 2002, pp 123-46.

3. Turkish Statistical Institute. Ages by statistics, 2016. [Internet] Available from: http://www.tuik.gov. tr/PreHaberBultenleri.do?id=24644. Accessed: 20.10.2017. (in Turkish).

4. Kalaycı I, Yazıcı SÖ, Özkul M, Küpeli A. Perceptions of the elderly on elderly abuse. Turkish Journal of Geriatrics 2016;19(4):232-7.

5. Health workers' violence research 2013. [Internet] Available from: http://www. sagliksen.org.tr/cdn/uploads/gallery/pdf/ fbda 8576 fd0d6d6de70f52f76b914672.pdf. Accessed: 20.10.2017.

6. Capezuti, E. Recognizing and referring suspected elder mistreatment. Geriatric Nursing 2011;32(3):20911. (PMID:21645804).

7. Ahmed A, Choo WY, Othman S, et al. Understanding of elder abuse and neglect among health care professionals in Malaysia: An exploratory survey. Journal of Elder Abuse \& Neglect 2016;28(3):163-77. (PMID:27149412).

8. O'Brien JG, Riain AN, Collins C, Long V, O'Neill D. Elder abuse and neglect: a survey of Irish general practitioners. Journal of Elder Abuse and Neglect 2014;26(3):291-9. (PMID:24779541).

9. Karadeniz G, Yanıkkerem-Uçum E, Dedeli Ö, Oran S, TalazD, Sürüm S. University students' consider toward elderly abuse. Family and Community Education Culture and Research Journal 2009;5(17):77-87. (in Turkish).

10. Anme T. A study of elder abuse and risk factors in Japanese families: focused on the social affiliation model. Geriatric and Gerontology International 2004;4:262-3.

11. Oh J, Kim HS, Martins D, Kim H. A study of elder abuse in Korea. International Journal of Nursing Studies 2006;43(2):203-14. (PMID:15913631).

12. Article 280-1 of Turkish Criminal Code numbered 5237. [Internet] Available from: https://www.tbmm. gov.tr/kanunlar/k5237.html.Accessed: 31.01.2018.
13. Rodríguez MA, Wallace SP, Woolf NH, Mangione CM. Mandatory reporting of elder abuse: between a rock and a hard place. Annals of Family Medicine 2006;4(5):403-9. (PMID:17003139).

14. Aydın B, Kartal M, Midik $O$, Büyükakkus A. Violence against general practioners in Turkey. J Interpers Violence 2009;24(12):1980-95. (PMID:19150889).

15. Taylor DK, Bachuwa G, Evans J, Jackson-Johnson V. Assessing barriers to the identification of elder abuse and neglect: a communitywide survey of primary care physicians. J Natl Med Assoc 2006;98(3):403-4. (PMID:16573305).

16. Kennedy RD. Elder abuse and neglect: the experience, knowledge and attitudes of primary care physicians. Fam Med 2005;37(7):481-5. (PMID:15988632).

17. Schmeidel AN, Daly JM, Rosenbaum ME et al. Health care professionals' perspectives on barriers to elder abuse detection and reporting in primary care settings. J Elder Abuse Negl 2011;24(1):17-36. (PMID:22206510)

18. Polat Ü, Bayrak Kahraman B. Knowledge and attitude of healthcare professionals about violence and abuse against elderly. Turkiye Klinikleri J Psychiatr Nurs-Special Topics 2017;3(2):141-52. (in Turkish).

19. Sugita J, Garrett M. Elder abuse and oral health care providers: an intervention to increase knowledge and self-perceived likelihood to report. J Elder Abuse Negl. 2012;24(1):50-64. (PMID:22206512).

20. Policastro C, Payne B. Assessing the level of elder abuse knowledge preprofessionals possess: implications for the further development of university curriculum. J Elder Abuse Negl 2014;26(1):12-30. (PMID:24313795).

21. Dow B, Hempton C, Cortes-Simonet EN, et al. Health professionals' and students' perceptions of elder abuse. Australasian Journal on Ageing 2013;32(1):48-51. (PMID:23521736).

22. Sorenson $H$. Verbal abuse and communication neglect in the elderly. In: R. W. Summers and A. M. Hoffman (Eds.). Elder Abuse: A Public Health Perspective. Washington, DC: American Public Health Association, USA 2006, pp 117-29. 